\title{
HUMAN GUT MICROBIOME AS AN INDICATOR OF HUMAN HEALTH
}

\author{
A.O. Ivanova, O.I. Yalovenko, O.M. Dugan* \\ Igor Sikorsky Kyiv Polytechnic Institute, Kyiv, Ukraine \\ *Corresponding author: duganaleksej2@gmail.com \\ Received 15 November 2021; Accepted 12 December 2021
}

\begin{abstract}
The undeniable achievement in the study of the gut microbiome as an association of different microorganisms, including viruses, that colonize various organs and systems of the body, is the establishment of the fact that some diseases that were consmicrobiotaidered as non-infectious can also be transmitted through microorganisms. This resulted in the gut microbiome being called a forgotten organ that could serve as an additional and kind of missing link for a more objective and better diagnosis and treatment of many diseases that were not considered infectious. The rapid development of gut microbiome research in recent years not only is connected with better understanding of the functioning of the microbiome by the scientific community, but also inseparable from the strategic support of each country. Global investment in researches, related to the human microbiome, has exceeded $\$ 1.7$ billion over the past decade. These researches contribute to the development of new diagnostic methods and therapeutic interventions. Our review is dedicated to the analysis of the possibilities of application of the human gut microbiome for the diagnosis of diseases, and the role of the intestines in the provocation and causing of certain diseases. Significant differences in the composition and diversity of the human microbiome are shown depending on geographical location and the change of socio-economic formations towards a gradual decrease in the diversity of the gut microbiome due to three stages of human population's existence: food production, agriculture and industrial urban life. We analyze the influence of dietary patterns, various diseases (including malignant neoplasms) and viral infections (in particular, coronavirus) on the gut microbiome. And vice versa - the influence of the gut microbiome on the drugs effect and their metabolism, which affects the host's immune response and course of the disease.
\end{abstract}

Keywords: human intestine; gut microbiome; coronavirus; immune response; drug metabolism.

\section{Introduction}

The human microbiome is an association of different species and types of microorganisms, including viruses, that colonize various organs and systems of the body, ranging from the skin and oral cavity to internal organs: respiratory tract, gastrointestinal tract, urinary tract, reproductive tract, etc. [1].

Over the past century, the world's scientific databases have accumulated enormous factual experimental material on research in various fields of microbiology, including (over the past few decades) research on the gut microbiome. If we imagine the volume of information on the gut microbiome, we can state the following: according to database Web of Science Core Collection, by 2005 the number of relevant publications was just over 500 per year while in 2019 alone over 9,500 publications have been published (over 2,000 are highly cited ones) 449 journals. The top 15 journals with the most cited articles on this topic are: Nature, Gut, Science, PNAS, Cell Host\&Microbe, Gastroenterology, Cell, PloS One, ISME Journal, Nature Communications, Nature Reviews Microbiology and Nature Reviews Gastroenteric Medicine [2].
Major countries that have made contributions to gut microbiota researches are the USA, China, the UK, Germany, France, Canada, Italy, Japan, Spain, the Netherlands and Australia.

An undoubted achievement in the study of the gut microbiota is the establishment of the fact that some diseases, which earlier were considered to be non-infectious, can also be transmitted through microorganisms. This led to the gut microbiome being called a forgotten organ that could serve as an additional and even a missing link for more objective and better diagnosis and treatment of many diseases that were not considered infectious [3]. As a result, in recent years more than $\$ 3$ billion has been invested in scientific research, related to the study of the gut microbiome [2].

In this artivle, we are aimed to present theoretical analysis of scientific information on the gut microbiome, which was published for the last 5 years. Acquisition and forming of knowledge in this field of medical microbiology will enable to use the obtained information more quickly and professionally for the purposes of detection and effective treatment of some diseases considered to be non-infectious. To achieve the set goal, it is necessary to perform the following objectives: 
- to analyze and establish the relevance of research basing on key financial indicators and the participation of different countries in research and publications on the topic of human gut microbiome;

- to highlight the general characteristic of the human microbiome and give its species composition and structure;

- to describe the external and internal influences on human gut microbial diversity;

- to analyze the impact of microorganisms from the environment on the human body and establish their role in the pathophysiology of diseases of different spectrum, as well as to outline methods of correction of dysbiotic conditions;

- to create a holistic view of practical advances in human gut microbiome research.

Identification of patterns of existence, development and interaction of certain types of microorganisms of the gut microbiome, that can affect the physiological state of the host in dependence to certain diseases and various pathological conditions, depends on the composition and structure of the human microbiome. The systemization and summarizing of the results, obtained in this study of the gut microbiome, makes it possible to identify its role in biological processes occurring in the human body.

\section{General characteristics and composition of the gut microbiome}

The composition and density of the human microbiota differs significantly from organ to organ and in different parts of the organ system. For example, the upper respiratory tract is more densely populated than the lower. The gastrointestinal tract (GIT), the stomach, duodenum and ileum (the lower part of the small intestine) are characterized by low density of microbial population, while the small intestine, cecum and large intestine are quite densely populated [4].

There is an outdated information that the ratio of "own microorganisms" (normal microbiota of human organs, existing pathogenic and conditionally pathogenic microorganisms in the body) and the human cells is 10:1. However, a refined estimation of the quantitative ratio of "human microorganisms" to the total number of macroorganism cells actually showed that there is 1 human cell for every 1.3 microorganism cells [5]. We should note that this approach to quantitative counting of human microbiome does not take into account fungi, viruses and phages present in various biotopes and, in the case of viruses and phages, may be equal to the number of bacteria or, according to [6], may exceed the number of the latter by at least an order of magnitude. Despite the fact that more accurate counts somewhat reduce the degree to which the number of microbial cells exceeds the number of human cells, the results of counts do not reduce the level of influence of human microbiome associated with the diversity of microbial life on the organism.

The species composition of the human microbiome is very diverse. An approximate estimate (and comparison) of 1,000 species of intestinal microorganisms with 2,000 genes per species (microorganism) was made. And it made possible to estimate 2,000,000 genes. This figure is 100 times higher than the usually assumed number of about 20,000 human genes.

As already noted, the intestines of a healthy person contain a number of bacterial cells roughly comparable to the number of cells that make up his body. It has been experimentally shown that an average fecal sample contains up to 700,000 bacterial genes, which is about 38 times more than the genes expressed by the human genome. Based on these data, it can be assumed that the metabolic capacity of the entire gut microbiota may exceed the metabolic capacity of the host organism. However, there is no numerical evidence in this sense yet [7].

If we consider the microbiome of an individual, it is estimated that 150 to 400 species live in the intestines of each individual [8]. Typically, most of these species belong to the following phyla: Bacteroidetes (consist of three large classes whose representatives are widely distributed in the environment, including soil, marine sediments, seawater and animal intestines), Firmicutes (a division of bacteria, most of which are Gram-positive, some have no cell wall at all and are not Gram-stained, but also have no outer membrane, found in other Gram-negative forms), Actinobacteria (gram-positive bacteria that are high in guanine and cytosine DNA and have a fungal-like mycelial structure, the largest subgroup is Actinomycetes) and Proteobacteria (a group of bacteria identified by their ribosomal RNA (16S rRNA) sequence, the most numerous group of bacteria, comprising 1,534 species, or about one-third of all known bacterial species).

The relative proportions of each of these taxa vary greatly between individuals [9] and even within an individual during his or her lifetime [10]. It is known that the microbiome of each individual is unique; however, when studying the microbiome of different human populations, several trends have been identified, as shown in Table 1 [11]. 
Table 1: Prevailing types and classes of human microbiome bacteria. Adopted from [11]

\begin{tabular}{|c|c|c|c|c|}
\hline $\begin{array}{l}\text { The } \\
\text { bacterial type }\end{array}$ & Class & Example & Localization & Characteristics \\
\hline Actinobacteria & $\begin{array}{l}\text { Acidimicrobia, } \\
\text { Actinobacteria, } \\
\text { Coriobacteriia, } \\
\text { Rubrobacteria, } \\
\text { Thermoleophilia, } \\
\text { Nitriliruptoria }\end{array}$ & $\begin{array}{l}\text { Corynebacterium, } \\
\text { Mycobacterium, } \\
\text { Nocardia, } \\
\text { Bifidobacterium, } \\
\text { Streptomyces }\end{array}$ & $\begin{array}{l}\text { Intestine, } \\
\text { oralcavity, skin }\end{array}$ & $\begin{array}{l}\text { Gram-positive, filamentous, } \\
\text { physiologically aerobic, } \\
\text { can be heterotrophic or } \\
\text { chemoautotrophic, but most are } \\
\text { chemoheterotrophic and can use } \\
\text { a wide range of food sources. }\end{array}$ \\
\hline Bacteroi detes & $\begin{array}{l}\text { Bacteroidia, } \\
\text { Flavobacteria } \\
\text { Sphingobacteria }\end{array}$ & $\begin{array}{l}\text { Bacteroides, } \\
\text { Prevotella }\end{array}$ & $\begin{array}{l}\text { Intestine, } \\
\text { oralcavity }\end{array}$ & $\begin{array}{c}\text { Aerobic and anaerobic, non- } \\
\text { sporulating, Gram-negative } \\
\text { bacilli }\end{array}$ \\
\hline Firmicutes & $\begin{array}{l}\text { Bacilli,Clostridia, } \\
\text { Erysipaelotrichia, } \\
\text { Thermolithobacteria, } \\
\text { Negativicutes }\end{array}$ & $\begin{array}{l}\text { Clostridium, } \\
\text { Staphylococcus, } \\
\text { Enterococcus, } \\
\text { Lactobacillus spp }\end{array}$ & $\begin{array}{c}\text { Bowel, } \\
\text { skin,stomach }\end{array}$ & $\begin{array}{l}\text { Gram-positive, bacilli,cocci, } \\
\text { spiral-shaped, anaerobic, } \\
\text { aerobic, include comensal } \\
\text { and beneficial } \\
\text { bacteria }\end{array}$ \\
\hline Proteobacteria & $\begin{array}{l}\text { Alphaproteobacteria, } \\
\text { Betaproteobacteria, } \\
\text { Gammaproteobacteria, } \\
\text { Deltaproteobacteria, } \\
\text { Epsilonproteobacteria }\end{array}$ & $\begin{array}{c}\text { Escherichia, } \\
\text { Salmonella, Vibrio, } \\
\text { Helicobacter, Yersinia, } \\
\text { Legionellales }\end{array}$ & Colon, skin & Gram-negative bacteria \\
\hline
\end{tabular}

The human digestive tract is $6.5 \mathrm{~m}$ long and consists of three organs: the stomach, small intestine and large intestine; however, most studies of the human microbiome have focused on the microbial association of the large intestine. Each milliliter of the large intestine (chyme) contains approximately $10^{11}$ microbial cells compared to $10^{8}$ cells in the small intestine [12].

Most of the information about the human gut microbiome was obtained through the following projects: the Human Microbiome Project (HMP) and the Human Gut Metagenomics Project (MetaHIT), funded by the US National Institutes of Health and the European Commission, respectively. However, it should be noted that the results obtained for the quantitative and qualitative composition of the gut microbiomes of the different countries populations, within the framework of the above projects, differ from each other in several parameters [13].

When comparing the quantitative and qualitative indicators of microbiomes, it was shown that their composition is more similar to each other within the same segment (e.g., oral cavity, small or large intestine) of different people than microbiomes of different segments of the same person. As for the individual representatives of microorganisms in different segments of the human body, it was shown that the oral cavities are inhabited by various representatives of the microbiome and, as a rule, they are dominated by Streptococcus spp. Skin areas are distinguished primarily by local skin properties (dry or wet) and are mainly inhabited by Corynebacterium, Propionibacterium and Staphylococcus species. A healthy vagina contains representatives of the genus Lactobacillus (a genus of gram-positive facultatively anaerobic bacteria that convert lactose and other sugars into lactic acid L. crispatus, L. iners, L. jensenii or L.gasser) [14]. A significant indicator of the state of female microbiota is their belonging to different races and ethnic groups, although even in this structured ecosystem intra-organismal variations are significant and to date have no fully explained causes. During human ontogenesis, the gut microbiome is formed under the influence of various factors. The most interesting and indicative is the variation of microbiome representatives depending on gestational age, method of newborn birth and method of feeding and human age [15]. The data of these studies are shown in Table 2.

Some important human segments usually have a particularly low microbial biomass in healthy individuals and therefore are more difficult to characterize. The lungs, for example, are almost sterile in the absence of infection or chronic disease, which leads not only to much interest in identifying their residents, but also includes considerable technical difficulties in sampling from these segments, so large-scale carefully controlled studies are needed to establish the functionality of these complex habitats of lowdensity microorganisms [16]. 
Table 2: Variation of microbiota depending on some exposure factors. Adopted from [15]

\begin{tabular}{|c|c|c|c|c|c|}
\hline & & Actinobacteria & Bacteroidetes & Firmicutes & Proteobacteria \\
\hline \multirow{3}{*}{ 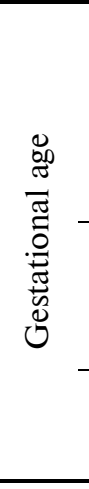 } & $\begin{array}{l}\text { Preterm } \\
\text { birth } \\
(<37 \text { weeks } \\
\text { gestation })\end{array}$ & $\begin{array}{l}\text { Bifidobacterium spp. } \downarrow \\
\quad \text { Atopobium spp. } \downarrow\end{array}$ & Bacteroides * $\downarrow$ & $\begin{array}{c}\text { Firmicutes }{ }^{*} \downarrow \\
\text { Lactobacillus } \uparrow \\
\text { Ruminococcus spp. } \\
\text { Lachnospiraceae* } \\
\text { Peptostreptococcaceae * } \\
\text { Clostridiaceae* }\end{array}$ & $\begin{array}{c}\text { Enterobacteriaceae }{ }^{*} \uparrow \\
\text { Enterococcus } \\
\text { spp. } \uparrow\end{array}$ \\
\hline & $\begin{array}{l}\text { Premature } \\
\text { babies }\end{array}$ & Bifidobacterium spp. $\uparrow$ & Bacteroidetes ${ }^{*} \uparrow$ & $\begin{array}{c}\text { Ruminococcus spp. } \\
\text { Lachnospiraceae* } \\
\text { Peptostreptococcaceae* } \\
\text { Clostridiaceae* }\end{array}$ & Enterobacteriaceae* \\
\hline & $\begin{array}{l}\text { Vaginal } \\
\text { birth }\end{array}$ & $\begin{array}{c}\text { Bifidobacterium spp. } \uparrow, \\
\text { Bifidobacterium catenulatum } \uparrow \\
\text { Bifidobacteriumlongum } \uparrow \\
\end{array}$ & $\begin{array}{c}\text { Prevotella } \uparrow \\
\text { Bacteroidesfragilis } \uparrow\end{array}$ & $\begin{array}{c}\text { Lactobacillus } \uparrow \\
\text { Staphylococcus } \uparrow \\
\text { Streptococcus } \uparrow \\
\end{array}$ & Escherichia $\uparrow$ \\
\hline 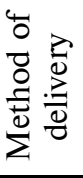 & $\begin{array}{l}\text { Caesarean } \\
\text { section }\end{array}$ & $\begin{array}{c}\text { Corynebacterium } \uparrow \\
\text { Propionibacterium } \uparrow\end{array}$ & Bacteroides * $\downarrow$ & Staphylococcus $\uparrow$ & $\begin{array}{c}\text { Escherichia } \downarrow \\
\text { Shigella } \downarrow\end{array}$ \\
\hline \multirow{3}{*}{ 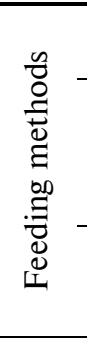 } & Breast milk & Bifidobacterium $\uparrow \uparrow$ & & $\begin{array}{c}\text { Lactobacillus } \uparrow \\
\text { Staphylococcus } \uparrow \\
\end{array}$ & Enterococcus $\uparrow$ \\
\hline & $\begin{array}{l}\text { Milk } \\
\text { substitutes }\end{array}$ & Bifidobacterium $\uparrow$ & Bacteroides $\uparrow$ & $\begin{array}{c}\text { Clostridium } \uparrow \\
\text { Clostridium } \\
\text { difficile } \uparrow \\
\text { Lactobacillus } \uparrow \\
\end{array}$ & Escherichia $\uparrow$ \\
\hline & Solid food & Bifidobacterium $\uparrow$ & $\begin{array}{c}\text { Bacteroidetes }{ }^{*} \uparrow \\
\text { Bacteroides } \uparrow\end{array}$ & $\begin{array}{c}\text { Firmicutes }{ }^{*} \uparrow \\
\text { Lactobacilli } \uparrow \\
\text { Clostridiumcoccoides } \uparrow \\
\end{array}$ & \\
\hline \multirow{3}{*}{ 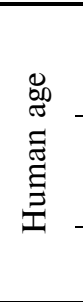 } & $\begin{array}{l}\text { The first year } \\
\text { of life }\end{array}$ & Bifidobacterium & Bacteroides & $\begin{array}{l}\text { Veillonella, } \\
\text { C. coccoides, } \\
\text { C. botulinum } \\
\end{array}$ & \\
\hline & $\begin{array}{l}\text { From } 2-3 \\
\text { years old } \\
\text { to adult } \\
\end{array}$ & $\begin{array}{l}\text { Bifidobacteriaceae* } \\
\text { Coriobacteriaceae* }\end{array}$ & $\begin{array}{l}\text { Bacteroidaceae * } \\
\text { Prevotellaceae } \\
\text { Rikenellaceae }\end{array}$ & $\begin{array}{l}\text { Lachnospiraceae } \\
\text { Ruminococcaceae }\end{array}$ & Proteobacteria* \\
\hline & $\begin{array}{l}\text { Over } 70 \\
\text { years old. }\end{array}$ & Bifidobacteriaceae $\downarrow$ & & Clostridium $* \downarrow$ & Proteobacteria $* \uparrow$ \\
\hline
\end{tabular}

Notes. *Unknown genera, $\uparrow$ increasing, $\downarrow$ decreasing.

\section{Differences in the composition and diversity of the human microbiome depending on the geographical location}

An important component of the study of the human microbiome is a comprehensive characterization of the microbiota of a healthy person, It is necessary for comparison and for the establishment of deviations from the norm during a disease. No less important is the establishment of indigenous (normal) microbiota of practically healthy people depending on their race and ethnicity. And, as recent studies have shown, there are significant differences in the structure of the microbiome of such population groups [17]. However, one should be aware that these data cannot be completely accurate because of the huge diversity of situations that can affect the final outcome of studies. But to draw an overall picture of the microbiomes of healthy humans of different origins, this information is certainly useful.

It is also indisputable that the change of socio-economic formations gradually influences the qualitative and quantitative composition of both the general human microbiome and (to a greater extent) the gut microbiome. These changes were accompanied by a gradual decreasing in the diversity of the microbiome, especially the gut microbiome. These phenomena can be explained by the fact that human populations have passed through three stages of existence, such as food extraction, agriculture and industrially developed urban life (if we count only purely industrial urban life; if we add to these figures the microbiomes of people engaged in agriculture, the overall picture changes somewhat). 
Researchers compared the diversity and composition of the gut microbiota of people of three different modes of existence:

- remote hunter-gatherer populations such as the Hadza (an indigenous people living in northern Tanzania - Arusha, Singida, Shinyanga regions, around Lake Eyasi); Pygmies (a group of stunted average height of adult males is less than 150 centimeters - negroid peoples living mainly in equatorial forests of Africa) and Indians (common name for the indigenous population of America from Venezuela, except for Eskimos and Aleuts, that was given to them by the navigator Christopher Columbus who discovered the continent India) [18, 19];

- traditional Bantu farming or fishing populations (a group of Central and Southern African peoples, the largest among them Rwanda, Makua, Shona, Congo, Malava, Runda, Zula, Kosa and others); Tunapuko (South American Indian) people in the Andes mountain regions or rural Malawian (small Malawian people, about 19,000 people) communities [20];

- representative group of western (US/European) urban industrialized society[21].

Hunter-gatherer populations mainly prefer starchy foods such as cassava tubers, plants, nuts, game and honey for sustenance. These remote gatherers suffer from multiple gastrointestinal microbial and parasitic infections. They have limited or no access to modern health facilities [22].

In contrast, the diet of traditional agriculturalists is similar to that of Neolithic people, when they moved from a nomadic lifestyle to a sedentary one, followed by the cultivation of food crops, domestication of animals, fishing and trade at a later stage of existence.

The diet of inhabitants of US or European metropolitan areas is high-protein and high-fat. This is accompanied by highly developed diagnostic, therapeutic and preventive medicine.

The results of these studies suggest that the factors of influence in the form of geographical affiliation of individuals can determine the causes of disease of different origins due to the fact that when environmental factors change, the gut microbiota adapts to new conditions by changing its qualitative and quantitative composition almost immediately [23].

\section{The impact of diet on the gut microbiome}

Numerous studies suggest that food can rapidly alter the qualitative composition of the gut micro- biota. A high-fat diet, or the so-called "Western" diet, is generally considered harmful to the brain [24]. Excessive consumption of high-fat foods is associated with an in the number of microorganisms of the following phyla: Firmicutes (mostly Grampositive bacteria) and Proteobacteria (see above) and a decrease in the number of Bacteroidetes (consists of three large classes, representatives widely distributed in the environment, including soil, marine sediment, seawater, and animal intestines). Such food also increases plasma and fecal acetate levels, triggers supersynthesis of insulin and ghrelin, and further promotes overeating [25]. The effects of obesity and inflammation caused by fatty foods may be reduced by polyphenols from fruits, accompanied by an increase in the number of Akkermansia muciniphila (a type of mucin-degrading human gut bacterium).

Switching to a high-fat or high-sugar diet from a low-fat or high-fiber diet can change the microbiome even in one day. A large numbers of Bacteroides are associated with the consumption of animal protein and saturated fats, while an increase in Prevotella (Prevotella spp. is part of the normal microbiota of the mouth, upper respiratory tract, vagina and other human organs, characteristic of the stomach of healthy people, infected and uninfected Helicobacter pylori) is associated with foods rich in carbohydrates and simple sugars. A vegetable-based diet increases the amount of short-chain fatty acids, which is accompanied by increased amounts of Prevotella and some Firmicutes that degrade fiber [26]. When food with fructose is consumed, the level of Bacteroidetes significantly decreases, while the number of Proteobacteria, Firmicutes and pathogenic Helicobacteraceae significantly increases [27].

Food derivatives and low-molecular-weight metabolites fermented by microorganisms are released by the gut microbiota into the bloodstream, which carries them throughout the body and further contributes to various diseases, including brain diseases [28].

\section{The human microbiome and diseases}

Determining the etiology of certain diseases associated with general and gut microbiota imbalance is important both in terms of treating these diseases and in terms of identifying the cause and effect. The causes of many diseases according to some researchers are "...physiological interactions between microbial groupings through physiological interactions between individuals..." [29], which is 
Table 3: Changes in gut microbiota and pathological status of organs [29]

\begin{tabular}{|c|c|c|}
\hline Organ & $\begin{array}{l}\text { Examples of diseases associated with altered } \\
\text { microbiota }\end{array}$ & Microbiota-mediated changes \\
\hline Brain & Autism spectrum disorders & Increased bacterial toxins,impaired fermentation \\
\hline Lungs & Asthma, cystic fibrosis & $\begin{array}{c}\text { Reduced immunologicaltolerance, altered gene } \\
\text { expression }\end{array}$ \\
\hline Heart & Cardiovascular diseases & Synthesis of proinflammatory metabolites \\
\hline Pancreas & Type 1 and 2 diabetes & Reduced insulin sensitivity \\
\hline Liver & Non-alcoholic fatty liver disease & Altered bile acid metabolism \\
\hline Fatty tissue & Metabolic syndrome, obesity & $\begin{array}{l}\text { Reduced intestinalgluconeogenesis, insulin } \\
\text { resistance }\end{array}$ \\
\hline $\begin{array}{l}\text { Gastrointestinal } \\
\text { tract }\end{array}$ & $\begin{array}{c}\text { Inflammatory bowel syndrome, irritable bowel } \\
\text { syndrome,intestinal infections }\end{array}$ & $\begin{array}{c}\begin{array}{c}\text { Dysregulated immune response, altered mucociliary } \\
\text { barrier }\end{array}\end{array}$ \\
\hline Leather & Acne, eczema, allergic diseases & $\begin{array}{c}\text { Increased pathogenic strains, dysregulated immune } \\
\text { response }\end{array}$ \\
\hline
\end{tabular}

true to some extent. It is further argued that many diseases are associated with a departure from a "healthy" gut microbiome. These include metabolic disorders, inflammatory and autoimmune diseases, neurological conditions and cancer. Certain gutrelated conditions (e.g., obesity and inflammatory bowel disease) have been extensively studied in human cohorts and in animal experiments, where significant, and sometimes causal, changes in microbial associations have been found. These studies have stimulated research into a number of complex diseases with unclear etiologies in which the microbiome is suspected to be associated [29]. Table 3 summarizes the data on the effect of altered qualitative composition of the gut microbiota on some diseases.

It is assumed that over the next few years there will be fundamentally new methods of treatment of various diseases caused by an altered gut microbiome. It is likely that the European Medicines Agency and the Food and Drug Administration will require all licensed medicines to be profiled for their effect on the gut microbiota, which is essentially a virtual organ. If a medicine damages this virtual organ, it cannot be licensed [30].

\section{Gut microbiome and malignant tumors}

Recently, there have been a growing number of researches on the influence of gut microbial groups on the risk of malignancy. The main purpose of these studies is to answer the question: does a tumor provoke a change in the qualitative composition of the gut microbiota? Numerous studies of this problem have yielded to proposal to divide the relationship between cancer and microbial communities into three categories: primary, secondary and tertiary categories of relationship.
Primary relationships are interactions (or influences of the microbiota) in the proximal (located closer to the center) tumor microenvironment. These interactions are important for understanding the mechanisms of microbiome-tumor relationships. As established for the $H$. pylori model, tumor can arise from microbial infections. In addition, products of the Gram-negative genus Fusobacterium (a genus of fibrous, anaerobic bacteria, similar to members of the Bacteroidetes fylum; individual species of this genus cause several human diseases) have been shown to be associated with the tumor microenvironment. Oncogenesis caused by Fusobacterium nucleatum is thought to result from opportunistic infection followed by chronic inflammation and immunosuppression, making F. nucleatum a tumor provoking factor in the primary microbiome-tumor interaction. The microorganism also generates bacterial biofilms that increase adaptation to microbial species; and its products contribute to tumor development and complement the hypoxic tumor microenvironment [31, 32].

Secondary relationships are interactions between tumors and the microbial association of a tissue, organ or organ system. These interactions are most important for identifying potential biomarkers for tissue screening for tumors. The digestive tract can attract some bacteria from the tumor, which can be used as a biomarker in tumor screening.

Tertiary relationships are interactions between the tumor and the distant microbiota. Tertiary interactions include therapeutic (in treatment) modulation by modification by chemotherapeutic drugs and reduction or increase in efficacy or toxicity of these drugs. Despite the physical distance of the individual organ systems that these microbial groupings occupy in relation to the tumor, that groups can have a strong influence on the tumor phenotype, treatment efficacy and outcomes. 


\section{Effects of human gut microbiota on drug metabolism}

In early 2018, new evidence was demonstrated for a link between the efficacy of anticancer drugs and resident bacteria in the body. Intestinal bacteria contain enzymes that can influence the activation or breakdown of drugs. Gut microorganisms are known to modulate the immune system and this phenomenon may be important in explaining the impact of the gut microbiome on cancer immunotherapy. Researchers have proposed several variations on how this works. For example, gut bacterial antigens may resemble tumor antigens, "training" the immune system to "fight" cancer [33]. It is considered most likely that the commensal microorganisms can activate the immune system.

In addition to linking the microbiome to cancer immunotherapy, scientists have begun to link resident microorganisms to drug efficacy for a wide range of pathological conditions in the body. It is reported that two-thirds of 276 different drugs involved in co-culture with 76 species of human intestinal bacteria were modified by them [34].

Given the wide range of influences of the microbiome, better knowledge of the interactions between resident microorganisms and drugs can change medical practice and will be combined with other types of information, such as genetics, to make treatments more individualized and effective.

\section{The role of human gut microbiota in metabolic diseases}

The results of numerous experimental and theoretical studies of the human gut microbiota indicate its significant role in metabolic diseases, including type 2 diabetes (T2DM).

The microbiota modulates inflammation, interacts with food components, influences intestinal permeability, glucose and lipid metabolism, insulin sensitivity, and overall energy homeostasis in the host [35].

Table 4 reflects changes in microbiota composition in type 2 diabetes [36].

However, despite numerous studies supporting the importance of the gut microbiota in the pathophysiology of this disease, this area of knowledge is at an early stage. At present, a point has been reached in the understanding that certain microbial taxa and their associated molecular mechanisms may be involved in the glucose metabolism associated with T2DM.
Table 4: Intestinal dysbiosis in type 2 diabetes

\begin{tabular}{ll}
\hline Bacterial type & \multicolumn{1}{c}{ Changes in species diversity } \\
& in type 2 diabetes \\
\hline \multirow{3}{*}{ Bacteroidales } & $\uparrow$ Bacteroides spp. \\
& $\uparrow$ Alistipes \\
& $\uparrow$ Parabacteroides \\
& $\downarrow \downarrow$ Clostridiales, $\uparrow$ Clostridium spp. \\
& $\downarrow$ Eubacterium rectale \\
& $\downarrow$ Faecalibacterium prausnitzii \\
Firmicutes & $\downarrow$ Roseburia spp. \\
& Lactobacillus gasseri \\
& $\uparrow$ Streptococcus mutans \\
\hline Proteobacteria & Escherichia coli \\
\hline Verrucomicrobia & $\downarrow \downarrow$ Akkermansia muciniphila \\
\hline
\end{tabular}

Notes. $\uparrow$ increasing, $\downarrow$ decreasing.

\section{The microbiome-gut-brain axis}

There is growing evidence that dynamic changes in the human gut microbiota can alter brain physiology and behavior. Researchers have identified changes in gut microbiota composition associated with several symptoms or diseases, such as pain, cognitive dysfunction, autism, neurodegenerative disorders and cerebral vascular disease [37].

The human microbiota of different localization promotes two-way transmission of brainintestinal signals through humoral, neural, and immunological pathways. The central nervous system is known to be involved in the regulation of intestinal motility and secretion, as well as in the regulation of mucosal immunity through the neuron-glial-epithelial pathway and visceral nerves, which contributes to changes in the intestinal microenvironment [38]. On the one hand, both external factors such as dietary habits, lifestyle, presence of own specific infections and early influence of environmental microbiota, and internal factors such as genetic determinants, metabolites, immunity and hormones play in the regulation of the qualitative-quantitative composition of gut microbiome. On the other hand, bacteria respond to these changes by producing neurotransmitters and neuromodulators in the gut that affect the host's central nervous system. These chemicals include: bacterial choline, tryptophan, short-chain fatty acids and hormones released from the gut, as well as, ghrelin and leptin. The relationship between brain impairment and corresponding changes in gut microbiota composition, indicating a clear link between gut microbiota and host physiology was summarized in Table 5 [28]. 
The human gut microbiota and viral infections. Coronavirus and the gut microbiome

The gut microbe regulates to some extent the host's protection against viral infections, including respiratory viruses such as the influenza viruses. This occurs by activating immune antiviral mechanisms and preventing excessive inflammation. Although data on the interaction between normal microbiota and viruses are limited, accumulating evidence with different interventions in the body, such as the effects of antibiotics and microbiota transfer (transplantation), has shown that the microbiota enhances antiviral immunity. The microbiota modulates the immune system by influencing the development of immune cells such as regulatory $\mathrm{T}$-cells and innate lymphoid cells that help to maintain gut and lung homeostasis [39].

The risk of severe COVID-19 infections is most common in people with hypertension, diabetes and obesity, conditions associated with changes in the composition of the gut microbiome. This raises the question of the role that gut microbiome plays in determining COVID-19 severity.

In New York 5,279 patients tested positive for COVID-19 between March 1 and April 8, 2020. Of these, $22.6 \%$ were diabetic and $35.3 \%$ were obese [40]. SARS-CoV and SARS-CoV-2 have $79.5 \%$ nucleotide sequence identity and use angiotensin-converting enzyme 2 (ACE2) receptors to enter host cells. The distribution of ACE2 may determine how SARS-CoV-2 affects the respiratory and digestive tract.

Although coronavirus 2 of severe acute respiratory syndrome (SARS-CoV-2) affects the tissues of the gastrointestinal tract, it is known a little about the role of intestinal commensal microorganisms in the susceptibility and severity of infection.

Patients with COVID-19 have significant changes in fecal microbial groups compared to the control group, that are characterized by an increase in the number of opportunistic microorganisms and depletion of beneficial commensals during hospitalization and at all times after hospitalization. Depleted symbionts and gut dysbiosis persist even after relief from SARS-CoV-2 and respiratory symptoms. The basal abundance in the gut of microorganisms such as Coprobacillus (a gram-positive, obligate anaerobic and immobile genus in the family Erysipelotrichidae, with one known species), Clostridium ramnosum and Clostridium hathewayi correlated with COVID-19 severity. Microorganisms such as Bacteroides dorei, Bacteroides thetaiotaomicron, Bacteroides massiliensis and Bacteroides ovatus were found in the gut of COVID-19 patients, which inhibit the expression of ACE2 and show an inverse correlation with severity [41].

Gut dysbiosis and epithelial inflammation increase levels of ACE2, a cell surface receptor that plays a key role in dietary amino acid homeostasis,

Table 5: The relationship between brain disorders and changes in gut microbiota [28]

\begin{tabular}{|c|c|}
\hline Brain disorders & Dysbacteriosis \\
\hline Stress and depression & $\begin{array}{l}\uparrow \text { Faecalibacterium, Alistipes, Ruminococcus, Campylobacter jejuni, Firmicutes; } \downarrow \\
\text { Bacteroidetes }\end{array}$ \\
\hline Pain and migraine & $\uparrow H$. pylori; dysbiosis \\
\hline Autism spectrumdisorders & $\begin{array}{l}\downarrow \text { Faecalibacterium spp., Bifidobacteria, Akkermansia muciniphila; } \uparrow \text { Lactobacillus, } \\
\text { Bacteroides, Prevotella, Alistipes; change in quantity of Fusobacteria, Verrucomicrobia, } \\
\text { Firmicutes/Bacteroides }\end{array}$ \\
\hline Parkinson's disease & $\begin{array}{l}\uparrow H . \text { pylori, E. coli, Ralstonia, Oscillospira, Bacteroides; } \downarrow \text { Prevotellaceae, Blautia, } \\
\text { Coprococcus, Roseburia }\end{array}$ \\
\hline Alzheimer's disease & $\begin{array}{l}\text { Chronic } H . \text { pylori infection; } \uparrow E \text {. coli, Salmonella spp, Pseudomonas fluorescens, Klebsiella } \\
\text { pneumoniae, Staphylococcus aureus, Bacillus subtills, Streptomyces coelicolor; Chlamydia } \\
\text { pneumoniae infection. }\end{array}$ \\
\hline $\begin{array}{l}\text { Amyotrophic } \\
\text { sclerosis }\end{array}$ & $\begin{array}{l}\text { Decreased levels of butyrate-producing bacteria, including Butyrivibrio fibrisolvens, } \\
\text { Escherichia coli, Oscillibacter,Anaerostipes, Lachnospira; }\end{array}$ \\
\hline Multiplesclerosis & $\begin{array}{l}\uparrow \text { Archaea, Psuedomonas, Haemophilus, Blautia, DoreaFusobacteria; } \downarrow \text { Bacteroidetes, } \\
\text { Firmicutes, Parabacteroides, Adlercreutzia, Prevotella, Bacteroides, Clostridia }\end{array}$ \\
\hline Atherosclerosis & $\begin{array}{l}\text { Lactobacillus rhamnosus, Neisseria polysaccharea,Acidovorax spp i H. pylori; Collinsella; } \\
\text { Roseburia, Eubacterium }\end{array}$ \\
\hline Stroke & $\begin{array}{l}\text { Porphyromonas gingivalis, Gram-negative bacteria, Enterobacter, Megasphaera, } \\
\text { Oscillibacter; } \uparrow \text { Bacteroides, Prevotella, Faecalibacterium }\end{array}$ \\
\hline & \\
\hline
\end{tabular}


innate immunity and gut microbial ecology. ACE2 is a target of SARS-CoV-2 [42]. Elevated levels of ACE2 in patients with an existing pro-inflammatory gut microbiome create conditions favorable for infection by a coronavirus [43], such as SARS-CoV-2, in the gut epithelium, from where it can spread throughout the body [44]. This is consistent with the development of gastrointestinal tract infections and the detection of viral RNA in the feces of many patients with COVID-19 (including persons with the negative PCR test of respiratory secretions) [45].

A recent study in Wuhan, China, confirmed the association between the composition of the gut microbiome and the susceptibility of healthy people to COVID-19 [46]. Elevated levels of microorganisms of Lactobacillus species correlate with higher levels of anti-inflammatory IL-10 and improve disease prognosis; elevated levels of proinflammatory bacteria including some Klebsiella species, Streptococcus, and Ruminococcus gnavus correlate with increased levels of pro-inflammatory cytokines and disease severity. Kawasaki disease, a condition similar to multisystem inflammatory syndrome in children that is increasingly reported as a complication in young children diagnosed with COVID-19 [47], is characterized by a dysbiotic gut microbiome with increased levels of Streptococcus species and decreased levels of Lactobacillus species compared to healthy individuals [48]. Consequently, COVID-19 induced changes in the composition of the gut microbiome may contribute to this complication.

\section{Development of new microbiome therapeutic drugs}

Most biotechnologies for microbiome recovery (correction) are developed by the US, Canadian and European companies. Recently, however, an increasing number are being located in other regions, such as China, South Korea and Israel. Microbiome-based drug developers are exploring virtually every possible approach to treating and diagnosing disease through the microbiome, using many different technologies.

Consider briefly implemented technologies.

Fecal microbiota transplantation. This approach generates interest in the treatment of disease using the microbiome of a healthy donor and rapidly expanded in the first time of use [49]. However, various regulatory requirements, safety requirements, have made it an afterthought in the industry: $6 \%$ of companies use this technology [50].
A specific consortium of microorganisms. This technology is based on treating a patient with a consortium of several bacterial species (usually two or more). While some of these technologies have evolved from further processing and refinement of fecal microbiota transplantation technology, some others have been developed with rational consideration of the ecological properties, metabolic capabilities or other characteristics of the microbial groupings. Given the technical complexity of these constructs, only about $7 \%$ of biotechnologies adhere to this strategy for treating disease.

One species (strain). According to this technique, one species of microorganism is entered into the body in order to cause a positive effect. This is a popular approach, followed by about $20 \%$ of programs. Most programs use targeted cross-linking between a specific bacterial strain and the immune system to treat inflammatory diseases and cancer (i.e., a personalized approach).

Phages. Using phages for elimination of bacteria and/or changing the composition of the microbiome is a technology used by about $10 \%$ of companies. The most obvious application of bacteriophages is the fight against infectious diseases, and this is indeed the area in which most projects are involved.

GMOs. While the metabolic capabilities of microorganisms are almost limitless and not yet fully described, some companies are creating bacteria to turn them into long-term drug delivery systems or expand or enhance their metabolic activity [51]. Due to technical and regulatory complexities of the approach, only $11 \%$ of companies use GMOs as therapeutic agents.

Microbiome metabolic products and postbiotics. Bacteria synthesize tens of thousands of different, chemically diverse substances, most of which have not been identified to date. Many of them are thought to have significant physiological effects and, therefore, may have enormous pharmacological potential $[52,53]$. Perhaps the most widely described chemicals synthesized by bacteria are antimicrobials and enzymes, and these are the main ones for research [54]. To date, there are several investigational enzymes that aim to break down antibiotics in the gut, which are administered systemically to prevent effects on the gut microbiome (thereby preventing gastrointestinal diseases caused by opportunistic microorganisms), and other enzymes as alternative therapy for certain metabolic diseases. 
Chemicals from the gut microbiome. With a greater understanding of the metabolic activity of the microbiome and its relationship to human physiology, there is a growing trend towards the use of external chemicals (mostly small molecules) to alter microbial activity to treat diseases such as immune conditions, irritable bowel syndrome and obesity [55]. This is a growing category (biotechnology) that is currently used by almost $20 \%$ of microbiome drug developers, but this proportion is likely to increase in the future.

\section{Conclusions}

The human gut microbiome has been attracting increasing attention from physicians and researchers over the past 15 years. The above data indicate that the rapid development of gut microbiome research in recent years is not only due to a better understanding of the function of the microbiome by the scientific community, but is also inseparable from the strategic support of each country. Global investment in research related to the human microbiome has exceeded $\$ 1.7$ billion over the past decade.

In the human body, the predominant bacterial types, including hundreds of genera and species, are Bacteroidetes, Firmicutes, Actinobacteria and Proteobacteria. The populations of these different bacterial species vary considerably from person to person, and the bacterial composition is perhaps primarily influenced by different environments and diets.

The gut microbiome underlies human health and is associated with many diseases. Current research on the gut microbiome is being transformed from correlation to causation, followed by a study of the mechanisms by which the microbiome affects host health.

The gut microbiome may also influence the action of drugs and their metabolism, affecting the host immune response and disease course.

In addition to discovering pathology and disease mechanisms, the study of the gut microbiome also contributes to the development of new diagnostic methods and therapeutic interventions. 6 . When analyzing diseases related to the gut microbiome, such as diarrhea, inflammatory bowel disease, irritable bowel syndrome, cardiovascular disease, autism, Alzheimer's disease, Parkinson's disease, it is important to remember that the gut microbiome is one aspect of disease and therefore its importance should not be overstated.

\section{References}

[1] Shreiner AB, Kao JY, Young VB. The gut microbiome in health and in disease. Curr Opin Gastroenterol. 2015;31(1):69-75. DOI: 10.1097/MOG.0000000000000139

[2] O'Hara AM, Shanahan F. The gut flora as a forgotten organ. EMBO Rep. 2006;7(7):688-93. DOI: 10.1038/sj.embor.7400731

[3] Li D, Gao C, Zhang F, Yang R, Lan C, Ma Y, et al. Seven facts and five initiatives for gut microbiome research. Protein Cell. 2020;11(6):391-400. DOI: 10.1007/s13238-020-00697-8

[4] Belizário JE, Napolitano M. Human microbiomes and their roles in dysbiosis, common diseases, and novel therapeutic approaches. Front Microbiol. 2015;6:1050. DOI: 10.3389/fmicb.2015.01050

[5] Sender R, Fuchs S, Milo R. Are we really vastly outnumbered? Revisiting the ratio of bacterial to host cells in humans? Cell. 2016;164(3):337-40. DOI: 10.1016/j.cell.2016.01.013

[6] Gilbert JA, Blaser MJ, Caporaso JG, Jansson JK., Lynch SV, Knight R. Current understanding of the human microbiome. Nature Med. 2018;24(4):392-400. DOI: 10.1038/nm.4517

[7] Rastelli M, Cani PD, Knauf C. The gut microbiome influences host endocrine functions. Endocrine Rev. 2019;40(5):1271-84. DOI: $10.1210 /$ er.2018-00280

[8] Lloyd-Price J, Abu-Ali G, Huttenhower C. The healthy human microbiome. Genome Med. 2016;8(1):51. DOI: $10.1186 / \mathrm{s} 13073-016-0307-\mathrm{y}$

[9] Human Microbiome Project Consortium. Structure, function and diversity of the healthy human microbiome. Nature. 2012;486(7402):207. DOI: 10.1038/nature11234

[10] Odamaki T, Kato K, Sugahara H, Hashikura N, Takahashi S, Xiao J-Z, et al. Age-related changes in gut microbiota composition from newborn to centenarian: a cross sectional study. BMC Microbiol. 2016;16(1):90. DOI: 10.1186/s12866-016-0708-5

[11] Dekaboruah E, Suryavanshi M, Chettri D, Verma AK. Human microbiome: an academic update on human body site specific surveillance and its possible role. Arch Microbiol. 2020;202(8):2147-67. DOI: 10.1007/s00203-020-01931-x

[12] Walter J, Ley R. The human gut microbiome: ecology and recent evolutionary changes. Annu Rev Microbiol. 2011;65(1):411-29. DOI: 10.1146/annurev-micro-090110-102830 
[13] Brito IL, Yilmaz S, Huang K, Xu L, Jupiter SD, Jenkins AP, et al. Mobile genes in the human microbiome are structured from global to individual scales. Nature. 2016;535(7612):435-9. DOI: 10.1038/nature18927

[14] DiGiulio DB, Callahan BJ, McMurdie PJ, Costello EK, Lyell DJ, Robaczewska A, et al. Temporal and spatial variation of the human microbiota during pregnancy. Proc Natl Acad Sci USA. 2015;112(35):11060-5. DOI: 10.1073/pnas.1502875112

[15] Rinninella E, Raoul P, Cintoni M, Franceschi F, Miggiano GAD, Gasbarrini A, et al. What is the healthy gut microbiota composition? A changing ecosystem across age, environment, diet, and diseases. Microorganisms. 2019;7(1):10-4. DOI: $10.3390 /$ microorganisms 7010014

[16] Paisse S, Valle C, Servant F, Courtney M, Burcelin R, Amar J, Lelouvier B. Comprehensive description of blood microbiome from healthy donors assessed by $16 \mathrm{~S}$ targeted metagenomic sequencing. Transfusion. 2016;56(5):1138-47. DOI: $10.1111 / \operatorname{trf} .13477$

[17] Gupta VK, Paul S, Dutta C. Geography, ethnicity or subsistence-specific variations in human microbiome composition and diversity. Front Microbiol. 2017;8:1162. DOI: 10.3389/fmicb.2017.01162

[18] Sankaranarayanan K, Ozga AT, Warinner C, Tito RY, Obregon-Tito AJ, Xu J, et al. Gut microbiome diversity among cheyenne and arapaho individuals from Western Oklahoma. Curr Biol. 2015;25(24):3161-9. DOI: 10.1016/j.cub.2015.10.060

[19] Rampelli S, Schnorr SL, Consolandi C, Turroni S, Severgnini M, Peano P, et al. Metagenome sequencing of the hadza hunter-gatherer gut microbiota. Curr Biol. 2015;25(13):1682-93. DOI: 10.1016/j.cub.2015.04.055

[20] Gomez A, Petrzelkova KJ, Burns MB, Yeoman CJ, Amato KR, Vlckova K, et al. Gut microbiome of coexisting BaAka pygmies and bantu reflects gradients of traditional subsistence patterns. Cell Rep. 2016;14(9):2142-53. DOI: 10.1016/j.celrep.2016.02.013

[21] Greenhill AR, Tsuji H, Ogata K, Natsuhara K, Morita A, Soli K, et al. Characterization of the gut microbiota of Papua New Guineans using reverse transcription quantitative PCR. PLoS One. 2015;10(2):427. DOI: 10.1371/journal.pone.0117427

[22] Morton ER, Lynch J, Froment A, Lafosse S, Heyer E, Przeworski M, et al. Variation in rural african gut microbiota is strongly correlated with colonization by entamoeba and subsistence. PLoS Genet. 2015;11(11):30. DOI: 10.1371/journal.pgen.1005658

[23] How ethnicity and geography affect your microbiome. [Internet]. GUTXY. 2021 [cited 2021 Nov 10]. Available from: https://www.gutxy.com/blog/how-ethnicity-and-geography-affect-your-microbiome

[24] Harrison CA, Taren D. How poverty affects diet to shape the microbiota and chronic disease. Nat Rev Immunol. 2018;18(4):279-87. DOI: 10.1038/nri.2017.121

[25] Perry RJ, Peng L, Barry NA, Cline GW, Zhang D, Cardone RL, et al. Acetate mediates a microbiome-brain-beta-cell axis to promote metabolic syndrome. Nature. 2016;534(7606):213-7. DOI: 10.1038/nature18309

[26] De Filippis F, Pellegrini N, Vannini L, Jeffery IB, La Storia A, Laghi L, et al. High-level adherence to a Mediterranean diet beneficially impacts the gut microbiota and associated metabolome. Gut. 2016;65(11):1812-21. DOI: 10.1136/gutjnl-2015-309957

[27] Li JM, Yu R, Zhang LP, Wen SY, Wang SJ, Zhang XY, et al. Dietary fructose-induced gut dysbiosis promotes mouse hippocampal neuroinflammation: a benefit of short-chain fatty acids. Microbiome. 2019;7(1). DOI: 10.1186/s40168-019-0713-7

[28] Zhu S, Jiang Y, Xu K, Cui M, Ye W, Zhao G, et al. The progress of gut microbiome research related to brain disorders. J Neuroinflammation. 2020;17(1):25. DOI: 10.1186/s12974-020-1705-Z

[29] Duvallet C, Gibbons SM, Gurry T, Irizarry RA, Alm EJ. Meta-analysis of gut microbiome studies identifies disease-specific and shared responses. Nat Commun. 2017;8(1):1784. DOI: 10.1038/s41467-017-01973-8

[30] Trials A. The Future of Microbiome Research [Internet]. News-Medical.net. 2021 [cited 2021 Nov 10]. Available from: https://www.news-medical.net/news/20201026/The-Future-of-Microbiome-Research.aspx

[31] Brennan CA, Garrett WS. Gut microbiota, inflammation, and colorectal cancer. Annu Rev Microbiol. 2016;70(1):395-411. DOI: 10.1146/annurev-micro-102215-095513

[32] Shang FM, Liu HL. Fusobacterium nucleatum and colorectal cancer: a review. World J Gastrointest Oncol. 2018;10(3):71-81. DOI: $10.4251 /$ wjgo.v10.i3.71

[33] Planas R, Santos R, Tomas-Ojer P, Cruciani C, Lutterotti A, Faigle W, et al. GDP-1-fucose synthase is a CD4+ T cell-specific autoantigen in DRB3 patients with multiple sclerosis. Sci Transl Med. 2018;10(462):eaat4301. DOI: 10.1126/scitranslmed.aat4301

[34] Maini Rekdal V, Bess EN, Bisanz JE, Turnbaugh PJ, Balskus EP. Discovery and inhibition of an interspecies gut bacterial pathway for Levodopa metabolism. Science. 2019;364(6445):eaau6323. DOI: 10.1126/science.aau6323

[35] Zimmermann M, Zimmermann-Kogadeeva M, Wegmann R, Goodman AL. Mapping human microbiome drug metabolism by gut bacteria and their genes. Nature. 2019;570(7762):462-7. DOI: 10.1038/s41586-019-1291-3

[36] Gurung M, Li Z, You H, Rodrigues R, Jump DB, Morgun A, et al. Role of gut microbiota in type 2 diabetes pathophysiology. EBioMedicine. 2020;51:102590. DOI: 10.1016/j.ebiom.2019.11.051

[37] Tilg H, Zmora N, Adolph TE, Elinav E. The intestinal microbiota fuelling metabolic inflammation. Nat Rev Immunol. 2019;20(1):40-54. DOI: 10.1038/s41577-019-0198-4

[38] Winek K, Dirnagl U, Meisel A. The gut microbiome as therapeutic target in central nervous system diseases: implications for stroke. Neurotherapeutics. 2016;13(4):762-74. DOI: 10.1007/s13311-016-0475-x 
[39] He Y, Wang J, Li F, Shi Y. Main clinical features of COVID-19 and potential prognostic and therapeutic value of the microbiota in SARS-CoV-2 infections. Front Microbiol. 2020;11:1302. DOI: 10.3389/fmicb.2020.01302

[40] Hepworth MR, Fung TC, Masur SH, Kelsen JR, Mcconnell FM, Dubrot J, et al. Group 3 innate lymphoid cells mediate intestinal selection of commensal bacteria-specific CD4+ T cells. Science. 2015;348(6238):1031-5. DOI: 10.1126/science.aaa4812

[41] Gut reaction: How the gut microbiome may inuence the severity of COVID-19 [Internet]. 2021 [cited 2021 Nov 10]. Available from: https://medicalxpress.com/news/2020-06-gut-reactionmicrobiome-severity-covid-.html

[42] Zuo T, Zhang F, Lui GCY, Yeoh YK, Li AYL, Zhan H, et al. Alterations in gut microbiota of patients with COVID-19 during time of hospitalization. Gastroenterology. 2020;159(3):944-55. DOI: 10.1053/j.gastro.2020.05.048

[43] Wang J, Zhao S, Liu M, Zhao Z, Xu Y, Wang P, et al. ACE2 expression by colonic epithelial cells is associated with viral infection, immunity and energy metabolism. medRxiv [Preprint] 2020. DOI: 10.1101/2020.02.05.20020545

[44] Chan JW, Kok KH, Zhu Z, Chu H, To KKW, Yuan S, et al. Genomic characterization of the 2019 novel human-pathogenic coronavirus isolated from a patient with atypical pneumonia after visiting Wuhan. Emerg Microbes Infect. 2020;9(1):221-36. DOI: $10.1080 / 22221751.2020 .1719902$

[45] Zhou J, Li C, Zhao G, Chu H, Wang D, Yan HHN, et al. Human intestinal tract serves as an alternative infection route for Middle East respiratory syndrome coronavirus. Sci Adv. 2017;3(11):15. DOI: 10.1126/sciadv.aao4966

[46] Xiao F, Tang M, Zheng X, Liu Y, Li X, Shan H. Evidence for gastrointestinal infection of SARS-CoV-2. Gastroenterology. 2020;158(6):1831-3. DOI: 10.1053/j.gastro.2020.02.055

[47] Gou W, Fu Y, Yue L, Chen GD, Cai X, Shuai M, et al. Gut microbiota may underlie the predisposition of healthy individuals to COVID-19. J Genet Genom. 2021;48(9):792-802. DOI: 10.1016/j.jgg.2021.04.002

[48] Jones VG, Mills M, Suarez D, Hogan CA, Yeh D, Segal JB, et al. COVID-19 and Kawasaki disease: novel virus and novel case. Hosp Pediatr. 2020;10(6):537-40. DOI: 10.1542/hpeds.2020-0123

[49] Cat L. The decade of the microbiome [Internet]. Forbes. 2021 [cited 2021 Nov 10]. Available from: https://www.forbes.com/sites/linhanhcat/2019/12/31/decade-of-the-microbiome/?sh=2458a4c29961

[50] Stripling J, Rodriguez M. Current evidence in delivery and therapeutic uses of fecal microbiota transplantation in human diseases-Clostridium difficile disease and beyond. Am J Med Sci. 2018;356(5):424-32. DOI: 10.1016/j.amjms.2018.08.010

[51] Safety Alert Regarding the Use of FMT \& Risk of Serious Adverse Events [Internet]. U.S. Food and Drug Administration. 2021 [cited 2021 Nov 10]. Available from: https://www.fda.gov/vaccines-blood-biologics/safety-availability-biologics/safetyalert-regarding-use-fecal-microbiota-transplantation-and-risk-serious-adverse-events-likely

[52] Sberro H, Fremin BJ, Zlitni S, Edfors F, Greenfield N, Snyder MP, et al. Large-scale analyses of human microbiomes reveal thousands of small, novel genes. Cell. 2019;178(5):1245-59. DOI: 10.1016/j.cell.2019.07.016

[53] Wilmanski T, Rappaport N, Earls JC, Magis AT, Manor O, Lovejoy J, et al. Blood metabolome predicts gut microbiome $\alpha$-diversity in humans. Nat Biotechnol. 2019;37(10):1217-28. DOI: 10.1038/s41587-019-0233-9

[54] Turroni S, Brigidi P, Cavalli A, Candela M. Microbiota-host transgenomic metabolism, bioactive molecules from the inside. J Med Chem. 2018;61(1):47-61. DOI: 10.1021/acs.jmedchem.7b00244

[55] Wang L, Ravichandran V, Yin Y, Yin J, Zhang Y. Natural products from mammalian gut microbiota. Trends Biotechnol. 2019;37(5):492-504. DOI: 10.1016/j.tibtech.2018.10.003

А.О. Іванова, О.І. Яловенко, О.М. Дуган

Київський політехнічний інститут ім. Ігоря Сікорського, Київ, Україна

\section{МІКРОБІОМ КИШЕЧНИКА ЛЮДИНИ ЯК ІНДИКАТОР ІЇ ЗДОРОВ’Я}

Беззаперечним досягненням у вивченні мікробіому кишечника як об'єднання різних мікроорганізмів, у тому числі вірусів, які населяють різні органи і системи людського організму, є встановлення того факту, що деякі захворювання, які вважалися неінфекційними, можуть бути опосередковані мікроорганізмами. Це привело до того, що мікробіом кишечника назвали “забутим органом”, який може слугувати додатковою (i, так би мовити, відсутньою) ланкою для більш об'єктивної та кращої діагностики і лікування багатьох захворювань, які не вважалися інфекційними. Швидкий розвиток досліджень мікробіому кишечника в останні роки не тільки пов'язаний із більш глибоким розумінням науковим співтовариством функції мікробіому, але і невіддільний від стратегічної підтримки кожної країни. Глобальні інвестиції в дослідження мікробіому людини за останнє десятиліття перевищили 1,7 млрд дол. Ці дослідження сприяють розробленню нових методів діагностики і терапевтичних втручань. Наша стаття присвячена аналізу можливостей використання мікробіому кишечника людини для діагностики сучасних захворювань та ролі кишківника у провокації та спричиненні певних захворювань. Показано суттєві відмінності в складі та різноманітності мікробіому людини залежно від географічного розташування і зі зміною суспільно-економічних формацій у бік поступового зменшення різноманітності мікробіому кишечника, що пояснюється трьома стадіями існування людської популяції: видобуток їжі, сільське господарство і промислово розвинене міське життя. Ми аналізуємо вплив на мікробіом кишечника характеру харчування, різноманітних захворювань (у т.ч. і злоякісних новоутворень) та вірусних інфекцій (зокрема, коронавірусу). I навпаки - вплив мікробіому кишечника на дію ліків та їхній метаболізм, що позначається на імунній відповіді господаря і перебігу хвороби.

Ключові слова: кишечник людини; мікробіом кишечника; коронавірус; імунна відповідь; метаболізм ліків. 


\section{А.О. Иванова, Е.И. Яловенко, А.М. Дуган}

Киевский политехнический институт им. Игоря Сикорского, Киев, Украина

\section{МИКРОБИОМ КИШЕЧНИКА ЧЕЛОВЕКА КАК ИНДИКАТОР ЕГО ЗДОРОВЬЯ}

Бесспорным достижением в изучении поведения микробиома кишечника как объединения различных микроорганизмов, в том числе вирусов, населяющих различные органы и системы человеческого организма, является установление того фракта, что некоторые заболевания, считавшиеся неинфекционными, могут быть опосредованы микроорганизмами. Это привело к тому, что микробиом кишечника назвали “забытым органом", который может служить дополнительным (и, так сказать, отсутствующим) звеном для более объективной и лучшей диагностики и лечения многих заболеваний, не считавшихся инфекционными. Быстрое развитие исследований микробиома кишечника в последние годы не только связано с более глубоким пониманием научным сообществом функции микробиома, но и неотделимо от стратегической поддержки каждой страны. Глобальные инвестиции в исследования микробиома человека за последнее десятилетие превысили 1,7 млрд долл. Эти исследования способствуюет разработке новых методов диагностики и терапевтических вмешательств. Показаны существенные отличия в составе и разнообразии микробиома человека в зависимости от географического расположения и с изменением общественноэкономических формаций в сторону постепенного уменьшения разнообразия микробиома кишечника, что объясняется тремя стадиями существования человеческой популяции: добыча пищи, сельское хозяйство и промышленно развитая городская жизнь. Мы анализируем влияние на микробиом кишечника характера питания, различных заболеваний (в т.ч. и злокачественных новообразований) и вирусных инфекций (в частности, коронавируса). И наоборот - влияние микробиома кишечника на действие лекарств и их метаболизм, что сказывается на иммунном ответе хозяина и течении болезни.

Ключевые слова: кишечник человека; микробиом кишечника; коронавирус; иммунный ответ; метаболизм лекарств. 